\title{
Perlindungan hukum atas dana nasabah pada bank melalui lembaga penjamin simpanan
}

\author{
Rilda Murniati \\ Bagian Hukum Keperdataan Fakultas Hukum Universitas Lampun \\ e-mail : rilda.murniatum@fh.unil.ac.id
}

\begin{abstract}
Abstrak
Kebutuhan masyarakat terhadap lembaga perbankan yang semakin meningkat. Untuk itu, diperlukan tindakan nyata dari lembaga perbankan dapat memberikan pelayanan yang terbaik bank dan harus mampu menjamin keamanan dana yang disimpan di bank. Keberadaan dan kegiatan bank sebagai tempat penyimpanan dana yang senantiasa akan berhadapan dengan adanya risiko, baik risiko akibat bank mengalami pailit atau dilikuidasi. Untuk itu, melalui Undang-Undang Nomor 24 Tahun 2004 tentang Lembaga Penjamin Simpanan, melahirkan kewajiban bagi setiap bank untuk menjaminkan dana nasabahnya melalui Lembaga Penjamin Simpanan (LPS). LPS adalah badan hukum yang berfungsi menjamin dana nasabah penyimpan yang disimpan di bank dalam bentuk giro, deposito, tabungan dan/atau yang dipersamakan dengan itu dengan nilai simpanan yang dijamin paling tinggi sebesar 2(dua) milyar rupiah per nasabah per bank. Apabila seorang nasabah memiliki beberapa rekening pada satu bank, maka untuk menghitung simpanan yang dijamin saldo seluruh rekening tersebut dijumlahkan. Pembayaran atas klaim penjaminan wajib dilakukan oleh LPS kepada nasabah dari bank yang dicabut izin usahanya setelah dilakukan rekonsiliasi dan verifikasi atas data simpanan yang layak dibayar dan simpanan yang tidak layak bayar. Pengajuan klaim penjaminan sudah wajib dilakukan oleh nasabah penyimpan paling lambat 5(lima) tahun sejak izin usaha bank dicabut. Dalam hal nasabah penyimpan tidak mengajukan klaim penjaminan atas simpanannya, maka hak nasabah penyimpan untuk memperoleh pembayaran klaim dari LPS menjadi hilang.
\end{abstract}

Kata kunci : perlindungan hukum, dana nasabah, lembaga penjaminan.

\section{Pendahuluan}

Bank adalah badan usaha yang diamanatkan oleh undang-undang untuk melakukan kegiatan menghimpun dana masyarakat berdasarkan kepercayaan. Untuk itu, pihak bank harus mampu menjaga kepercayaan masyarakat yang telah menyimpan dananya pada bank dan menjamin bahwa dana yang mereka simpan pada bank tersebut aman, artinya kapanpun mereka membutuhkan dan mengambil kembali dananya, pihak bank menjamin dana tersebut ada sehingga masyarakat merasa aman dan nyaman untuk selalu menyimpan kembali dananya pada bank tersebut. Masyarakat pengguna jasa pada lembaga perbankan lazim disebut nasabah bank. Terdapat 2 jenis nasabah bank yaitu nasabah penyimpan dan nasabah peminjam. Ditinjau dari segi nasabah penyimpan, alasan nasabah menyimpan dananya di bank antara lain untuk keamanan, dalam hal ini 
keamanan dana yang disimpan di bank lebih terjamin dari pada disimpan sendiri di rumah. Ditinjau dari segi nasabah peminjam, alasan nasabah meminjam dana di bank adalah bunga pinjaman yang relatif lebih kecil dibandingkan jika meminjam kepada rentenir atau lintah darat.

Berdasarkan kebutuhan masyarakat terhadap lembaga perbankan yang semakin meningkat dan untuk menjaga kepercayaan masyarakat terhadap bank, diperlukan tindakan nyata dari lembaga perbankan selain memberikan pelayanan yang terbaik bank juga harus mampu menjamin keamanan dana yang disimpan. Keberadaan nasabah menjadi suatu kebutuhan mutlak bagi sebuah bank mengingat nasabah adalah sumber keuntungan bagi bank, baik yang berupa bunga pinjaman maupun dari dana nasabah yang tersimpan di bank yang dikelola bank untuk dipinjamkan kembali kepada nasabah peminjam. Kegiatan bank menerima dana dari masyarakat untuk disimpan dan kemudian menyalurkan kembali dana yang tersimpan tersebut kepada masyarakat, menjadikan bank sebagai tempat tersedianya dana baik yang berupa uang kartal (uang tunai) maupun uang giral (giro, deposito, dan lain-lain).

Sehubungan dengan keberadaan dan kegiatan bank sebagai tempat penyimpanan dana yang senantiasa menghadapi risiko, baik risiko akibat bank mengalami pailit atau dilikuidasi. Jika kerugian terjadi akibat bank dilikuidasi maka dana nasabah yang tersimpan akan dikembalikan dan dibayar oleh Lembaga Penjamin Simpanan (LPS) karena kewajiban setiap bank menjadi peserta LPS.
Lembaga Penjamin Simpanan (LPS) adalah sebuah lembaga yang dibentuk berdasarkan ketentuan dalam Undang-Undang Nomor 24 Tahun 2004 tentang Lembaga Penjamin Simpanan sebagaimana telah diubah dengan Undang-Undang Nomor 7 Tahun 2009. Penjaminan simpanan nasabah bank oleh LPS bersifat terbatas tetapi dapat mencakup sebanyak-banyaknya nasabah. Dalam hal bank tidak dapat melanjutkan usahanya karena dicabut izin usahanya, LPS bertanggung jawab membayar simpanan setiap nasabah bank tersebut sampai jumlah Rp. 2 000.000.000,- (dua milyar rupiah). Adapun untuk jumlah sisa simpanan yang tidak dijamin, akan diselesaikan melalui proses likuidasi bank. Hal ini disebabkan bank yang melakukan kegiatan usaha adalah sebagai peserta penjaminan yang diselenggarakan LPS. Dengan adanya pembayaran premi oleh bank kepada LPS maka telah terjadi pelimpahan risiko dari bank kepada LPS.

II. Pembahasan

\section{Status dan Fungsi Lembaga Penjamin Simpanan berdasarkan UU LPS}

UU Nomor 24 Tahun 2004
tentang Lembaga
Pimpanan (UU LPS) ditentukan
secara tegas dalam Bab II dalam
Pasal 2 dan Pasal 3 UU LPS
mengenai status LPS. Berdasarkan
Pasal 2 UU LPS, ditentukan bahwa
LPS adalah badan hukum yang
bersifat independen, transparan, dan
akuntabel dalam menjalankan tugas
dan wewenangnya dan LPS
bertangung jawab kepada Presiden.
Dalam penjelasan UU LPS
dinyatakan yang dimaksud dengan


independensi bagi LPS mengandung arti bahwa dalam pelaksanaan tugas dan wewenangnya, LPS tidak bisa dicampurtangani oleh pihak manapun termasuk oleh pemerintah.

Mengingat bahwa kebijakan penjaminan dapat berdampak pada sektor perbankan dan fiskal maka di dalam LPS terdapat wakil dari masing-masing otoritas yang berwenang. Keberadaan wakil otoritas tersebut dimaksudkan untuk bersama-sama merumuskan kebijakan penjaminan yang dapat mendukung kebijakan pada sektorsektor tersebut. Namun, pelaksanan kebijakan tersebut merupakan sepenuhnya tanggung jawab dan kewenangan LPS tanpa dapat dicampurtangani oleh pihak manapun. Sebagai contoh dalam menyelesaikan tugas penanganan bank yang dicabut ijin usahanya, khususnya dalam rangka penjualan atau pengalihan aset bank tersebut LPS tidak dapat dipengaruhi oleh kepentingan pihak luar termasuk pemerintah.

Pasal 3 UU LPS menentukan bahwa LPS berkedudukan di ibukota Negara Republik Indonesia dan dapat mempunyai kantor perwakilan di wilayah Negara Republik Indonesia. Ketentuan mengenai peryaratan dan tata cara pembentukan kantor perwakilan diatur dengan keputusan dewan komisioner. Pasal 1 Ayat (13) UU LPS menentukan bahwa dewan Komisioner adalah organ tertinggi dari LPS.

Sebagai lembaga yang berstatus badan hukum maka LPS harus memenuhi syarat atau kriteria badan hukum yang ditetapkan berdasarkan doktrin ilmu hukum sebagai berikut ${ }^{1}$

\section{a. Memiliki Kekayaan sendiri}

Badan hukum merupakan pendukung kewajiban dan hak sama seperti manusia pribadi. Sebagai pendukung kewajiban dan hak, dia dapat mengadakan hubungan bisnis dengan pihak lain. Untuk itu, dia memiliki kekayaan sendiri, yang terpisah dari kekayaan pendiri atau pengurusnya. Segala kewajiban hukumnya dipenuhi dari kekayaan yang dimilikinya itu. Dalam anggaran dasar biasanya ditentukan jumlah dan rupa kekayaan badan hukum. Kekayaan badan hukum ini terpisah dari kekayaan pribadi pengurus atau pendirinya dan ini ditentukan secara tegas dalam anggaran dasar dan dicatat dalam pembukuan perusahaan.

Pasal 81 UU LPS menentukan tentang kekayaan yang dimiliki LPS sebagai kekayaan yang telah dipisahkan dari kekayaan negara dan ditetapkan melalui Peraturan Pemerintah setelah berkonsultasi dengan Dewan Perwakilan Rakyat (DPR).. Berdasarkan Pasal 81 UU LPS tersebut ditentukan bahwa modal awal LPS ditetapkan sekurang-kurangnya Rp. 4.000.000.000.000,- (empat triliun rupiah) dan sebesar-besarnya $\mathrm{Rp}$. 8.000.000.000.000,- (delapan triliun rupiah). Modal LPS tersebut berasal dari aset negara yang dipisahkan dan tidak terbagi dalam bentuk saham. Oleh karena itu LPS harus dapat bertanggungjawab atas pengelolaan dan penatausahaan atas semua asetaset yang dimilikinya.

\footnotetext{
1 Abdulkadir Muhammad, Hukum Perusahaan Indonesia, Cetakan Revisi Keempat, 2010, hlm.101-102.
} 
Pasal 81 UU LPS tersebut membuktikan bahwa LPS adalah badan hukum yang memiliki kekayaan sendiri yang terpisah dari kekayaan milik negara. Jumlah kekayaan tersebut harus dicantumkan dalam Anggaran Dasar LPS berdasarkan peraturan pemerintah tentang pemisahan kekayaan negara pada LPS. Oleh karena itu, LPS memenuhi kriteria badan hukum berupa kekayan sendiri yang terpisah dari kekayaan pemiliknya yaitu negara.

\section{b. Diwakili Oleh Pengurus}

Agar dapat berbuat menurut hukum, maka badan hukum diurus oleh pengurus yang ditetapkan dalam Anggaran Dasarnya sebagi yang berwenang mewakili badan hukum. Artinya perbuatan pengurus adalah perbuatan badan hukum. Perbuatan pengurus tersebut selalu mengatasnamakan badan hukum, bukan atas nama pribadi pengurus. Segala kewajiban yang timbul dari perbuatan pengurus adalah kewajiban badan hukum, yang dibebankan pada harta kekayaan badan hukum. Sebaliknya pula, segala hak yang diperoleh dari perbuatan pengurus adalah hak badan hukum yang menjadi kekayaan badan hukum.

Pasal 62 UU LPS menentukan bahwa LPS terdiri atas Dewan komisioner dan Kepala Eksekutif. Selanjutnya Pasal 63 UU LPS menentukan bahwa Dewan Komisioner adalah pimpinan LPS. Tugas dewan komisioner adalah merumuskan dan menetapkan kebijakan serta melakukan pengawasan dalam rangka pelaksanaan tugas dan wewenang LPS sebagaimana diatur dalam undang-undang ini.
Dewan Komisioner dipimpin oleh seorang ketua. Salah satu anggota Dewan Komisioner yang ditetapkan sebagai Kepala Eksekutif bertugas melaksanakan kegiatan operasional LPS. Tugas dan wewenang Kepala Eksekutif ditetapkan dalam Keputusan Dewan Komisioner (Pasal 64 UU LPS). Pasal 65 UU LPS menentukan bahwa anggota Dewan Komisioner berjumlah 6 (enam) orang diangkat oleh Presiden atas usul Menteri Keuangan dengan masa jawbatan 5 (lima) tahun. Salah satu dari anggota tersebut ditetapkan Presiden sebagai Ketua Dewan Komisioner (Pasal 66 UU LPS).

Pengaturan LPS tersebut membuktikan bahwa LPS adalah badan hukum yang memenuhi kriteria badan hukum yaitu memiliki organisasi yang dipimpin atau diwakili oleh pengurus. Perbuatan pengurus yaitu Dewan Komisioner merupakan perbuatan LPS dan menjadi tanggung jawab LPS.

\section{c. Anggaran Dasar Disahkan oleh Pemerintah}

Anggaran dasar badan hukum harus mendapat pengesahan secara resmi dari Menteri. Pengesahan oleh Menteri merupakan pembenaran bahwa anggaran dasar badan hukum yang bersangkutan tidak bertentangan dengan undang-undang, tidak bertentangan dengan ketertiban umum dan kesusilaan. Di samping itu pengesahan juga menentukan bahwa sejak tanggal pengesahan itu diberikan, maka sejak itu pula badan usaha yang bersangkutan memperoleh status badan hukum dan dengan demikian memiliki harta kekayaan sendiri yang terpisah dari harta kekayaan pribadi pengurus atau pendirinya. 
Berdasarkan Pasal 2 UU LPS ditentukan bahwa LPS adalah badan hukum yang bertanggung jawab kepada Presiden. Selanjutnya Pasal 65 dan Pasal 66 UU LPS menetapkan bahwa LPS dipimpin oleh Dewan Komisioner yang diusulkan oleh Menteri Keuangan dan diangkat dengan Keputusan Presiden. Keputusan Presiden tersebut kemudian harus dituangkan dalam Anggaran Dasar LPS. Anggaran Dasar LPS adalah pedoman kerja bagi LPS dalam menjalankan fungsi, tugas, dan wewenangnya berdasarkan UU LPS. Untuk itu, Anggaran Dasar LPS harus disetujui oleh Menteri Keuangan sebagai wakil pemerintah yang akan mengawasi kegiatan usaha LPS.

Berdasarkan penjelasan tersebut di atas dapat dibuktikan dalam pengaturan LPS telah ditentukan bahwa LPS sebagai badan hukum memenuhi kriteria ketiga badan hukum berupa anggaran dasar yang disetujui oleh pemerintah. Sebagai lembaga yang berstatus badan hukum dan dibentuk oleh pemerintah untuk melakukan penjaminan terhadap simpanan nasabah bank berdasarkan UndangUndang Nomor 24 Tahun 2004 tentang Lembaga Penjamin Simpanan (UU LPS), maka terhadap LPS diberikan fungsi, tugas dan wewenang yang telah diatur dalam UU LPS.

Pasal 4 mengatur bahwa fungsi LPS adalah menjamin simpanan nasabah penyimpan dan turut aktif dalam memelihara stabilitas sistem perbankan sesuai dengan kewenangannya. Dalam menjalankan fungsi sebagaimana dimaksud dalam Pasal 4 UU LPS, maka LPS memiliki tugas untuk merumuskan dan menetapkan kebijakan pelaksanan penjaminan simpanan dan melaksanakan penjaminan simpanan.

Penjaminan simpanan nasabah penyimpan meliputi pula penjaminan bentuk yang setara dengan simpanan bagi bank yang menggunakan prinsip syariah. Untuk itu, LPS dalam menjalankan fungsi memelihara stabilitas system keuangan bersamasama dengan menteri keuangan, bank Indonesia, dan Lembaga Pengawas Perbankan (LPP) sesuai dengan peran dan tugasnya masing-masing. Dalam menjalankan fungsi sebagaiman dimaksud dalam Pasal 4 huruf a yaitu menjamin simpanan nasabah, maka Pasal 5 Ayat (1) UU LPS menentukan bahwa LPS mempunyai tugas:

a. merumuskan dan menetapkan kebijakan dalam rangka turut aktif memelihara stabilitas sistem perbankan;

b. melaksanakan penjaminan simpanan.

Selanjutnya, untuk menjalankan fungsi sebagaimana ditentukan dalam Pasal 4 huruf b yaitu turut aktif dalam memelihara stabilitas sistem perbankan sesuai dengan kewenangannya, maka Pasal 5 Ayat (2) UU LPS menetapkan bahwa LPS mempunyai tugas yaitu:

a. merumuskan dan menetapkan kebijakan dalam rangka turut aktif memelihara stabilitas sistem perbankan;

b. merumuskan, menetapkan dan melaksanakan kebijakan penyelesaian bank gagal (bank resolution) yang tidak berdampak sitematik, dan

c. melaksanakan penanganan bank gagal yang berdampak sistemik setelah berkonsolidasi dengan 
Menteri Keuangan, bank Indonesia dan LPP.

Pasal 6 UU LPS menentukan bahwa dalam rangka melaksanakan tugas sebagaimama dimaksud dalam Pasal 5, LPS mempunyai kewenangan sebagai berikut:

a. menetapkan dan memungut premi simpanan;

b. menetapkan dan memungut kontribusi pada saat bank pertama kali menjadi peserta;

c. melakukan pengelolaan kekayaan dan kewajiban LPS;

d. mendapatkan data simpanan nasabah, data kesehatan bank, laporan keuangan bank, dan laporan hasil pemeriksaan bank sepanjang tidak melanggar kerahasian bank;

e. melakukan rekonsiliasi, verifikasi, dan atau konfirmasi atas data;

f. menetapkan syarat, tata cara, dan ketentuan pembayaran klaim;

g. menunjuk, menguasakan, dan atau menugaskan pihak lain untuk bertindak bagi kepentingan dan atau atas nama LPS;

h. melakukan penyuluhan kepada bank dan masyarakat tentang penjaminan simpanan;

i. menjatuhkan sanksi administratif terhadap bank yang melakukan pelanggaran kewajiban kepada LPS.

Bank gagal (failing bank) adalah bank yang mengalami kesulitan keuangan dan membahayakan kelangsungan usahanya serta dinyatakan tidak dapat lagi disehatkan oleh LPP sesuai dengan kewenangan yang dimilikinya. Berdasarkan penjelasan Pasal 5 UU LPS ditentukan bahwa LPS bersama dengan Menteri Keuangan, Bank Indonesia, dan LPP merumuskan kebijakan penyelesaian bank gagal. LPS merumuskan dan menetapkan kebijakan yang diperlukan dalam rangka pelaksanaan penyelesaian bank gagal yang tidak berdampak sistemik yang telah dinyatakan oleh LPP sebagai tidak dapat disehatkan lagi berdasarkan kewenangan yang dimilikinya.

Adapun yang dimaksud dengan penyelesaian bank gagal atau dalam istilah perbankan disebut resolusi bank (bank resolution) adalah :

a. Menyelamatkan bank gagal; atau

b. Tidak menyelamatkan bank gagal.

LPS melaksanakan kebijakan dan merumuskan pelaksanaan penanganan bank gagal yang berdampak sistemik yang telah diputuskan oleh Komite Koordinasi. Pasal 1 Ayat (9) menyatakan bahwa Komite Koordinasi adalah komite yang beranggotakan Menteri Keuanga, LPP, Bank Indonesia, dan LPS yang memutuskan kebijakan penyelesaian dan penanganan suatu bank gagal yang ditenggarai berdampak sistemik.

Pasal 21 UU LPS mengatur mengenai pengambilan keputusan dalam penyelesaian dan penanganan bank gagal. LPS menerima pemberitahuan dari Lembaga Pengawasan Perbankan (LPP) mengenai bank bermasalah yang sedang dalam upaya penyehatan sebagaimana dimaksud dalam peraturan perundang-undangan di bidang perbankan. LPS melakukan penyelesaian bank gagal yang tidak berdampak sistemik setelah LPP menyerahkan penyelesaiannya kepada LPS. Sedangkan penanganan yang dilakukan pada bank gagal yang berdampak sistemik setelah komite koordinasi menyerahkan penanganannya kepada LPS. 
Penyelesaian bank gagal yang tidak berdampak sistemik sesuai Pasal 22 UU LPS dilakukan dengan cara penyelamatan atau tidak melakukan penyelamatan terhadap bank gagal dimakud. Sedangkan Penyelesaian bank gagal yang berdampak sistemik dilakukan dengan melakukan penyelamatan yng mengikut sertakan pemegang saham lama atau tanpa mengikut sertakan pemegang saham lama. Keputusan untuk melakukan penyelamatan atau tidak melakukan penyelamatan terhadap bank gagal ditetapkan oleh LPS, dengan sekurang-kurangnya didasarkan pada perkiraan biaya penyelamatan dan perkiraan biaya tidak melakukan penyelamatan terhadap bank gagal yang dimaksud. LPS melakukan perhitungan atas perkiraan biaya penyelamatan dan perkiraan biaya tidak melakukan penyelamatan terhadap bank gagal sebagaimana dimaksud. Perkiraan biaya untuk melakukan penyelamatan bank gagal sebagaimana dimaksud diatas diatur dalam Pasal 23 yaitu meliputi penambahan modal sampai bank tersebut memenuhi ketentuan tingkat solvabilitas dan tingkat likuiditas. Perkiraan biaya tersebut juga harus memperhitungkan biaya pembayaran simpanan nasabah yang dijamin, biaya talangan gaji terutang, talangan pesangon pegawai dan perkiraan penerimaan LPS dari penjualan aset bank yang dicabut izin usahanya.

Upaya penyelamatan bank gagal yang tidak berdampak sistemik berdasarkan Pasal 24 UU LPS harus memenuhi persyaratan antara lain:

a. Perkiraan biaya penyelamatan secara signifikan harus lebih rendah dari perkiraan biaya tidak melakukan penyelamatan bank dimaksud. b. Setelah diselamatkan bank masih menunjukkan prospek usaha yang baik

c. Ada pernyataan dari RUPS bank yang sekurang-kurangnya memuat kesediaan untuk menyerahkan hak dan wewenang RUPS kepada LPS, menyerahkan kepengurusan bank kepada LPS dan tidak menuntut LPS atau pihak yang ditunjuk LPS apabila proses penyelamatan tidak berhasil, sepanjang LPS melakukan tugasnya sesuai dengan peraturan yang berlaku; dan

d. Bank menyerahkan kepada LPS dokumen yang antara lain mengenai penggunaan fasilitas keuangan dari Bank Indonesia, data keuangan dan informasi lain yang terkait dengan permodalan yang dibutuhkan LPS.

Setelah persyaratan sebagaimana dimaksud dalam Pasal 24 UU LPS tersebut terpenuhi maka sesuai dengan ketentuan Pasal 25 UU LPS, RUPS harus menyerahkan segala hak dan wewenang yang dimilikinya kepada LPS. Setelah RUPS menyerahkan seluruh hak dan wewenangnya kepada LPS maka sesuai ketentuan Pasal 26 UU LPS, LPS dapat melakukan tindakan sebagai berikut :

a. Menguasai, mengelola dan melakukan tindakan kepemilikan atas aset milik atau yang menjadi hak dan kewajiban bank.

b. Melakukan penyertaan modal sementara.

c. Menjual atau mengalihkan aset bank tanpa persetujuan nasabah debitur dan/atau kewajiban bank tanpa persetujuan nasabah debitur. 
d. Mengalihkan manajemen bank kepada pihak lain.

e. Melakukan merger atu konsolidasi dengan pihak lain

f. Melakukan pengalihan kepemilikan bank; dan

g. Meninjau ulang, membatalkan, mengakhiri dan mengubah kontrak bank yang mengikat bank dengan pihak ketiga yang menurut LPS merugikan bank.

Seluruh biaya yang telah dikeluarkan oleh LPS dalam upaya penyelamatan bank yang bersangkutan berdasarkan Pasal 27 UU LPS menjadi penyertaan modal sementara LPS pada bank. Dalam upaya penyelamatan bank gagal yang berdampak sistemik, pemegang saham ikut berperan dengan cara penyetoran modal (open bank assistance). Penanganan terhadap bank gagal dengan cara tersebut diatas hanya dapat dilakukan apabila:

a. Pemegang saham bank gagal telah menyetor modal sekurangkurangnya $20 \%$ (dua puluh persen) dari perkiraan biaya penanganan.

b. Ada pernyataan dari RUPS bank yang sekurang-kurangnya memuat kesediaan untuk menyerahkan hak dan wewenang RUPS kepada LPS, menyerahkan kepengurusan bank kepada LPS dan tidak menuntut LPS atau pihak yang ditunjuk LPS apabila proses penyelamatan tidak berhasil, sepanjang LPS melakukan tugasnya sesuai dengan peraturan yang berlaku; dan

c. Bank menyerahkan kepada LPS dokumen yang antara lain mengenai penggunaan fasilitas pendanaan dari Bank Indonesia, data keuangan nasabah debitur dan data aset serta permodalan yang dibutuhkan LPS.

LPS juga memiliki wewenang untuk melakukan likuidasi terhadap bank yang dinyatakan gagal. Dalam rangka melakukan likuidasi terhadap bank gagal yang dicabut izin usahanya maka LPS melakukan tindakan sesuai Pasal 43 UU LPS sebagai berikut:

a. Mengambil alih dan menjalankan segala hak dan menguasai serta mengelola aset serta menjual atau mengalihkan aset bank yang dinyatakan gagal tersebut.

b. Memberikan talangan untuk pembayaran gaji pegawai yang terutang dan talangan pesangon pegawai sebesar jumlah minimum pesangon.

c. Melakukan tindakan pengamanan aset bank sebelum proses likuidasi dimulai.

d. Memutuskan pembubaran badan hukum bank, membentuk tim likuidasi dan menyatakan status bank sebagai bank dalam likuidasi.

Setelah bank tersebut dinyatakan sebagai bank dalam likuidasi, maka LPS wajib membayar klaim penjaminan dari bank yang dicabut izin usahanya kepada para nasabah penyimpan dana. Pembayaran klaim penjaminan dapat dilakukan secara tunai atau dengan alat pembayaran lain yang setara dengan itu dan setiap pembayaran klaim penjaminan dilakukan dengan mata uang rupiah.

\section{Bentuk Perlindungan Hukum bagi Nasabah Bank Berdasarkan UU LPS}

Apabila suatu saat terjadi merosotnya kepercayaan masyarakat 
terhadap lembaga perbankan, maka hal tersebut merupakan suatu bencana bagi ekonomi negara secara keseluruhan dan keadaan tersebut sangat sulit untuk dipulihkan kembali. Adanya resiko besar yang terjadi apabila kepercayaan masyarakat terhadap lembaga perbankan merosot, maka tidak berlebihan apabila usaha perlindungan bagi para nasabah yang telah menyimpan dananya pada lembaga perbankan mendapat perhatian yang khusus dengan lahirnya UU LPS.

Perlindungan hukum bagi nasabah bank dalam bertransaksi dengan baik, khususnya nasabah penyimpan sebelum berlakunya Undang-Undang Nomor 24 Tahun 2004 tentang Lembaga Penjamin Simpanan belum mendapatkan tempat yang memadai. UndangUndang Nomor 10 Tahun 1998 tentang perubahan atas UndangUndang Nomor 7 Tahun 1992 tentang Perbankan, tidak mengatur secara langsung perlindungan bagi nasabah. Dalam Bab V Pasal 29 ayat (1), (2), (3) dan ayat (4), yang mengatur mengenai ketentuan pembinaan dan pengawasan bank, memberikan konsekuensi bagi Bank Indonesia untuk lebih efektif dalam melakukan pembinaan dan pengawasan terhadap bank.

Sebagai lembaga pembina dan pengawas perbankan di Indonesia, Bank Indonesia mempunyai peran yang besar dalam upaya melindungi dan menjamin agar nasabah bank tidak mengalami kerugian akibat pengelolaan manajemen bank yang salah. Bank Indonesia wajib aktif melakukan tugas dan kewenangannya untuk mengawasi pelaksanaan ketentuan perundangundangan oleh seluruh bank yang ada di Indonesia. Pengawasan yang efektif dan baik merupakan langkah pencegahan (preventif) dalam mengurangi kasus-kasus yang menimpa nasabah akibat tindakan yang salah dari bank.

Ketidaktegasan perlindungan hukum terhadap nasabah yang diatur dalam Undang-Undang Perbankan, maka mengharuskan pembinaan dan pengawasan bank merupakan hal yang sangat penting dilakukan oleh Bank Indonesia secara berkesinambungan.

$$
\text { Adanya Undang-Undang }
$$

Nomor 24 Tahun 2004 tentang Lembaga Penjamin Simpanan (LPS), berupaya memberikan perlidungan hukum dan kepastian hukum bagi nasabah penyimpan dana, sehingga diharapkan dapat menimbulkan kepercayaan masyarakat terhadap jasa perbankan dan dapat mengurangi resiko yang membebani anggaran negara. Penjaminan simpanan nasabah bank tersebut diselenggarakan oleh Lembaga Penjamin Simpanan (LPS). Pasal 8 UU LPS merupakan ketentuan yang memberikan kewajiban kepada setiap bank yang melakukan kegiatan usahanya di wilayah Negara Republik Indonesia menjadi peserta penjaminan.

Bentuk perlindungan yang diberikan kepada nasabah atas simpanannya pada bank melalui LPS adalah merupakan wujud dari fungsi LPS. LPS memiliki dua fungsi yaitu menjamin simpanan nasabah bank dan melakukan penyelesaian atau penanganan bank gagal. Untuk itu, melalui ketentuan UU LPS dan fungsi serta tugas LPS nasabah memperoleh perlindungan hukum atas simpanan dana pada bank. 


\section{a. Simpanan Nasabah yang dijamin LPS}

Pengaturan UU LPS yang berkaitan dengan bentuk simpanan yang dijamin oleh Lembaga Penjamin Simpanan (LPS) berupa giro, deposito, sertifikat deposito, tabungan, dan/atau bentuk lain yang dipersamakan dengan itu (Pasal 10 UU LPS). Berdasarkan ketentuan Pasal 10 UU LPS tersebut, maka simpanan yang dijamin LPS adalah sebagai berikut ${ }^{2}$ :

(1) Simpanan yang dijamin meliputi giro, deposito, setifikat deposito, tabungan, dan atau bentuk lain yang dipersamakan dengan itu;

(2) Simpanan nasabah bank berdasarkan prinsip syariah yang dijamin meliputi: giro, berdasarkan prinsip wadiah, tabungan berdasarkan prinsip wadiah dan prinsip mudharabah muthlaqah atau muqayyadah yang risikonya oleh bank, deposito berdasarkan prinsip mudharabah muthlaqah atau muqayyadah yang risikonya ditanggung oleh bank, dan/atau;

(3) Simpanan yang dijamin merupakan simpanan yang berasal dari masyarakat, termasuk yang berasal dari bank lain;

(4) Nilai simpanan yang dijamin Lembaga Penjamin Simpanan mencakup saldo pada tanggal pencabutan izin usaha bank;

(5) Saldo yang dijamin untuk setiap nasabah pada satu bank adalah hasil penjumlahan saldo seluruh rekening simpanan nasabah pada bank tersebut, baik rekening

2 Adrian Sutedi, Aspek Hukum Lembaga Penjamin Simpanan, Sinar Grafika, Jakarta, 2010, hlm.68-70 tunggal maupun rekening gabungan (joint account)

Selanjutnya, di dalam Pasal 11 Ayat (1) UU LPS diatur mengenai nilai simpanan yang dijamin untuk setiap nasabah pada suatu bank paling banyak Rp. 100.000 .000 (seratus juta rupiah). Namun, Peraturan Pemerintah Nomor 66 Tahun 2008 tentang Besaran Nilai Simpanan yang Dijamin LPS maka terdapat perubahan nilai simpanan yang dijamin adalah paling banyak Rp.2.000.000.000,- (dua milyar rupiah) dan ketentuan ini tidak berlaku terhadap simpanan nasabah pada bank yang telah dicabut izin usahanya sebelum berlakunya peraturan pemerintah ini. Selanjutnya, ketentuan ini dikukuhkan keberlakuannya dalam Undang-Undang Nomor 7 Tahun 2009 tentang Penetapan PP Pengganti UU Nomor 3 Tahun 2008 tentang Perubahan atas UU Nomor 24 Tahun 2004 tentang Lembaga Penjamin Simpanan.

Berdasarkan ketentuan peraturan perundang-undangan tersebut, maka nilai simpanan yang dijamin oleh LPS adalah paling tinggi sebesar 2(dua) milyar per nasabah per bank. Apabila seorang nasaba mempunyai beberapa rekening simpanan pada satu bank maka untuk menghitung simpanan yang dijamin saldo seluruh rekening tersebut dijumlahkan. ${ }^{3}$

\section{b. Pembayaran Penjaminan oleh LPS}

Klaim

Pembayaran atas klaim penjaminan wajib dilakukan oleh Lembaga Penjamin Simpanan (LPS) kepada nasabah dari bank yang

${ }^{3}$ Ibid. 
dicabut izin usahanya setelah dilakukan rekonsiliasi dan verifikasi atas data simpanan yang layak dibayar dan simpanan yang tidak layak bayar. Rekonsiliasi dan verifikasi dilakukan secara bertahap berdasarkan rekening yang lebih mudah diverifikasi. Penentuan simpanan yang layak dibayar selambat-lambatnya 90 (sembilan puluh) hari kerja terhitung sejak izin usaha bank dicabut dan pembayaran mulai dilakukan selambat-lambatnya dalam waktu 15 (lima belas ) hari kerja terhitung sejak verifikasi dimulai. Ketentuan tersebut diatur dalam Pasal 16 ayat (1), Ayat (2), Ayat (3), dan Ayat (4) UU LPS.

Pasal 16 Ayat (1) UU LPS mengatur bahwa LPS wajib membayar klaim penjaminan kepada nasabah penyimpan dari bank yang dicabut izin usahanya. Pasal 16 Ayat (2) LPS berhak memperoleh data nasabah penyimpaan dan informasi lain yang diperlukan per tanggal pencabutan izin usaha dari LPP dan/atau bank dalam rangka perhitungan dan pembayaran klaim penjaminan. Pasal 16 Ayat (3) UU LPS mengatur LPS wajib menentukan simpanan yang layak dibayar, setelah melakukan rekonsiliasi dan verifikasi atas data sebagaimana dimaksud pada ayat (2) selambat-lambatnya 90 (sembilan puluh) hari kerja terhitung sejak izin usaha bank dicabut.

Penjelasan pasal tersebut menyatakan bahwa data dan informasi yang diterima LPS untuk menentukan simpanan yang layak dibayar dapat berasal dari berbagai sumber. Untuk itu perlu dilakukan proses untuk membandingkan, mencocokkan menentukan serta memastikan data dan informasi yang akan digunakan untuk menentukan simpanan yang layak dibayar. Proses tersebut memerlukan waktu sebelum pembayaran klaim penjaminan dapat mulai dilakukan.

Adapun yang dimaksud dengan simpanan yang layak dibayar adalah simpanan yang sesuai dengan peraturan yang terdapat dalam UU LPS. Pasal 16 ayat (4) UU LPS mengatur LPS mulai membayar simpanan yang layak dibayar selambat-lambatnya dalam waktu 5 (lima) hari kerja terhitung sejak verifikasi dimulai.

Lembaga Penjamin Simpanan mengumumkan tanggal pengajuan klaim atas simpanan yang layak dibayar pada sekurang-kurangnya dua surat kabar harian yang berperedaran luas. Pengumuman tersebut memuat syarat dan tata cara pengajuan klaim atas simpanan yang layak di bayar yang diajukan oleh nasabah penyimpan kepada LPS sesuai pengumuman. Pengajuan klaim penjaminan sudah wajib dilakukan oleh nasabah penyimpan paling lambat 5(lima) tahun sejak izin usaha bank dicabut. Dalam hal nasabah penyimpan tidak mengajukan klaim penjaminan atas simpanannya, maka hak nasabah penyimpan untuk memperoleh pembayaran klaim dari LPS menjadi hilang. Untuk itu, nasabah tersebut diperlakukan sama dengan nasabah yang simpanannya tidak dijamin oleh LPS. Nasabah penyimpan yang hilang haknya untuk memperoleh pembayaran klaim penjaminan dari LPS diperlakukan sama dengan nasabah penyimpan yang simpanannya tidak dijamin dan diselesaikan berdasarkan mekanisme likuidasi. 
Cara pembayaran klaim kepada nasabah penyimpan adalah sebagai berikut: $^{4}$

(1) Pembayaran klaim dilakukan berdasarkan simpanan yang layak bayar sesuai dengan hasil rekonsiliasi dan verifikasi;

(2) Simpanan layak bayar tersebut dibayarkan oleh LPS melalui bank pembayar yang ditunjuk;

(3) Pembayaran klaim dilakukan paling lambat 5(lima) hari kerja setelah tanggal rekonsiliasi dan verifikasi dimulai;

(4) Dalam hal terdapat nasabah penyimpan yang sebagian dari saldo rekeningnya tidak dibayar oleh LPS karena saldo simpanan tersebut melebihi jumlah maksimum simpanan yang dijamin maka, LPS menerbitkan surat keterangan mengeni saldo rekening yang tidak dibayar tersebut;

(5) Pembayaran klaim tersebut dilakukan secara tunai dengan mata uang rupiah dan setara tunai, antra lain dengan mengalihkan rekening nasabah penyimpan tersebut kepada bank pembayar.

Lahirnya UU LPS, maka dapat dinyatakab dengan tegas bahwa Undang-Undang ini memberikan jaminan kepastian hukum atas dana nasabah yang disimpan di bank dengan jumlah yang cukup besar dan tata cara pengajuan dan jangka waktu pengajuan yang cukup panjang yaitu paling lambat 5(lima) tahun sejak bank dicabut izin usahanya. Dengan demikian, jaminan yang diberikan oleh peraturan perundang-undangan tentang penjaminan simpanan nasabah oleh LPS dapat meningkatkan kepercayaan

${ }^{4}$ Ibid, hlm.72 masyarakat atas lembaga perbankan dan memanjukan stabilitas perekonomian masyarakat dan negara termasuk bila timbul masalah pada lembaga perbankan hak atas nasabah bank dijamin oleh undangundang.

\section{Simpulan}

1. LPS adalah badan hukum yang bersifat independen, transparan, dan akuntabel dalam menjalankan tugas dan wewenangnya dan LPS bertanggung jawab kepada Presiden berfungsi menjamin dana nasabah penyimpan yang disimpan di bank dalam bentuk giro, deposito, tabungan dan/atau yang dipersamakan dengan itu dengan nilai simpanan yang dijamin paling tinggi sebesar 2 (dua) milyar rupiah per nasabah per bank. Apabila seorang nasabah memiliki beberapa rekening pada satu bank, maka untuk menghitung simpanan yang dijamin saldo seluruh rekening tersebut dijumlahkan.

2. Pembayaran atas klaim penjaminan wajib dilakukan oleh LPS kepada nasabah dari bank yang dicabut izin usahanya setelah dilakukan rekonsiliasi dan verifikasi atas data simpanan yang layak dibayar dan simpanan yang tidak layak bayar. Pengajuan klaim penjaminan sudah wajib dilakukan oleh nasabah penyimpan paling lambat 5(lima) tahun sejak izin usaha bank dicabut. Dalam hal nasabah penyimpan tidak mengajukan klaim penjaminan atas simpanannya, maka hak nasabah 
penyimpan untuk memperoleh pembayaran klaim dari LPS menjadi hilang.

\section{Daftar Pustaka}

Djumhana, Muhammad. 2003. Hukum Perbankan di Indonesia. Citra Aditya Bakti, Bandung.

Hartono, Sri Rejeki, 1992.Praktik Hukum Dagang di Indonesia. Bintang Terang, Yogyakarta.

Muhammad, Abdulkadir. 2004. Hukum dan Penelitian Hukum, Citra Aditya Bhakti, Bandung. 2010.

Hukum Perusahaan

Indonesia Cetakan Revisi Keempat. Citra Aditya Bakti, Bandung.

dan Rilda Murniati. 2004. Lembaga Keuangan dan Pembiayaan. Citra Aditya Bakti, Bandung.

Meliala, A. Qirom Syamsudin. 2002. Perbankan di Indonesia, Bina Cipta, Jakarta.

Sudaryatmo. 1999. Hukum dan Advokasi Konsumen. Citra Aditya Bakti, Bandung.

Sutedi, Adrian. 2010. Aspek Hukum Lembaga Penjamin Simpanan. Sinar Grafika, Jakarta. 